\title{
Battle at Bond Bluff: Forecasters vs. Financial Markets
}

\author{
Kevin L. Kliesen
}

$\mathrm{O}$ n June 30, 2004, when the FOMC upped its intended federal funds rate by 25 basis points to 1.25 percent, the data indicated that core CPI had risen by about 1.75 percent for that year (May 2003 to May 2004) and yields on 10-year Treasury securities had averaged about 4.75 percent that month. It worried policymakers somewhat that core inflation and longterm interest rates had moved noticeably higher over the previous few months and that the spot price of crude oil (West Texas Intermediate) was up a little less than 25 percent from a year earlier. Still, the latest Blue Chip Consensus forecast projected solid real GDP growth in 2005 (3.5 percent), with moderate CPI inflation (2.2 percent); the Blue Chip does not forecast the core CPI.

As it stands now, the federal funds rate has been raised to 3 percent and oil prices are up even more; however, as seen in the chart, the Blue Chip Consensus forecast for real GDP growth has been remarkably stable. Indeed, the forecast for real GDP growth in 2005 has remained within a fairly narrow range for most of the past year despite a rise in the spot price of oil to an average of $\$ 54.31$ per barrel by March 2005, an increase of more than 58 percent since January 2004. (The chart indexes oil prices to be 1 in January 2004.)

In a recent speech, Federal Reserve Bank of St. Louis President William Poole remarked that "the stability of the economy is reflected in the stability of the forecasts." But while forecasts for real GDP growth in 2005 have been remarkably stable, forecasts for core CPI inflation in 2005 have been moving steadily higher. According to the private-sector forecasting firm Macroeconomic Advisers, the expected increase in the core CPI in 2005 has risen from 1.7 percent in January 2004 to 2.5 percent in May 2005. If realized, the 2005 increase would be the highest core inflation rate in four years.

The steady rise in core inflation forecasts is potentially worrisome in view of the role that expectations have come to play in the policymaking process. Over time, monetary policymakers have realized that they can potentially exert influence over economic activity by affecting expectations of future inflation. Hence, a key part of economic stability is the expectation of low inflation.

Yet, as the chart also shows, financial markets appear to have shrugged off the upcreep in expected core inflation. After peaking at an average of about 4.75 percent in June 2004, the yield on the 10-year Treasury security has dropped to about 4 percent. The fall in long-term interest rates in the face of rising inflation, higher oil prices, and continued solid growth prospects is something of a puzzle. If anything, a decline in long-term yields in the face of stable economic growth prospects usually means the market is betting on lower future inflation-implying that the market views the recent rise in inflation as temporary.

But another view emerged in May, as forecasters trimmed their 2005 real GDP growth forecast to 3.2 percent. This revision, more or less, was consistent with the story that long-term interest rates were declining because of an expectation of weaker growth going forward (lower real yields). It is possible, though, that this downward revision in the 2005 forecast was a response to the weaker-than-expected advance estimate of first-quarter real GDP growth (3.1 percent). Since then, first-quarter growth has been revised upward to 3.5 percent and several indicators of economic conditions in April have come in much better than expected. If nominal interest rates continue to remain stable in the face of solid growth, then the interest rate puzzle may simply reflect a more sanguine inflation outlook from the bond market than from forecasters.

\section{Forecasts for 2005 (Q4/Q4) and Oil Prices and Long-Term Interest Rates}

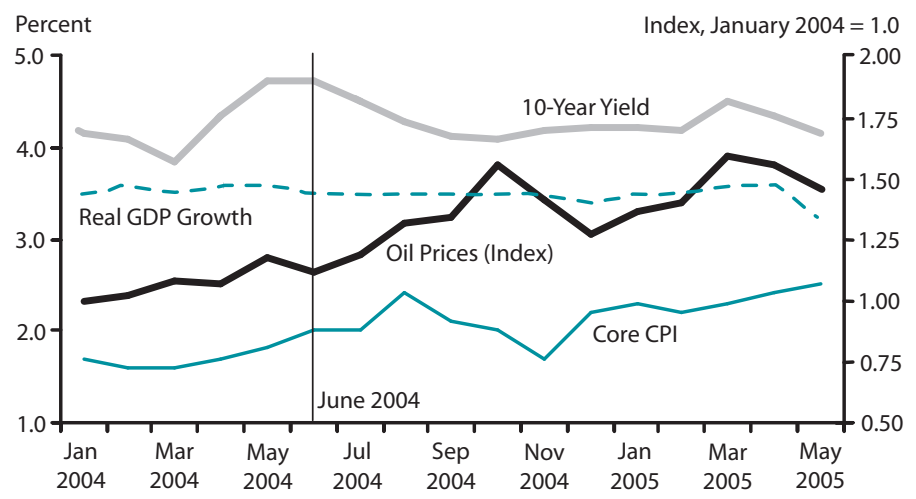

SOURCE: Federal Reserve Bank of St. Louis, Blue Chip Indicators (real GDP), and Macroeconomic Advisers (Core CPI). 